Next was produced a gold medal, given to Mr. Creaming for his proficiency in nursing little children. It represented him sitting in a rocking-chair, with a puncheon of warm water by his side, and removing a soiled napkin from an obstreperous young urchin. Then a silver medal, which showed on one side Mr. Creaming lecturing a number of ladies, who expected to be confined at no distant day; and on the reverse, $\mathbf{M r}$. Creaming's sensitive feelings were portrayed as being deeply wounded, - a closed gum-lancet was lying on a table, and this caused him to shut his eyes, compress his teeth, and cover his face with both his hands. Next there was unrolled a long sheet of paper, on which several figures were painted. "That, gentlemen" said he, "I value beyond all price; it was given me as an especial mark of approbation by the governors of the London Hospital, in which I studied, and it was the work of an eminent artist. This painting," he continued, "represents Mr. Daisy Creaming as he was seen walking the hospital on November, 18-; he is pouring balm and oil into the wounds inflicted on the hand of a rat-catcher by a ferocious rat. Observe in the back-ground a number of hard-hearted students, ridiculing his humanity, while that impostor, Fischecrackum, cruelly and indecently applies his right thumb to the tip of his nose, and wagging his little finger insultingly, cries out, "humbug."

Lastly came a recommendation from the apothecary, with whom Daisy served seven long years of apprenticeship, the wording of which ran thus :-

"Mr. Daisy Creaming, my late pupil, was for a period of seven years under my tuition and constant observation. I invariably found him a quiet and tender-hearted young inan. Of many instances that $I$ could relate in proof of the delicate sensibility which pervades his soul, I shall here only mention one. Mr. Daisy Creaming had been under my care about twelve months, when it so happened that I was necessitated to send him to administer an alvine injection to an elderly maiden lady. He begoed hard to be excused undertaking the task, but there was no alternative left but for him to discharge the duty. When first he arrived at the house, he left the instrument down stairs, covering it with his handkerchief lest the sight thereof should excite any unnecessary alarm. At the bed-side of the patient most silently did he place the vessel containing the mixture of castor oil, salts, and warm gruel, that constituted the prescribed glyster; then having. gently drawn up the well-oiled piston, lest any clattering sound should grate on the nerves of the aged spinster, he with a trembling hand conveyed the pipe to within an inch of its destination. Then, stopping short, he tenderly inquired whether he caused any pain, as well as the agitation of the moment would allow; - she replied, "a little;" -and he gradually advanced the pipe yet nearer and nearer, but as soon as it came in contact with the body she uttered a piercing scream, which so overpowered the excited nerves of Mr. Daisy, that he fell backwards in a swoon, upsetting the glyster upon his best black trousers, which he had specially put on for the occasion; and, what was worse, an unfortunate but nameless accident occurred during his state of insensibility, that placed Mr. Daisy in that condition in which it was desired to have placed the intended recipient of the glyster."

I had observed Mr. Creaming's countenance, previous to this point, give signs of inward feeling, but when the account of this sad catastrophe was wound up to a close, he burst into a fit of sobbing, and rushed from the room.

I shall not detail at much length how Dr. Peedlewhiski brought in with him a capacious urinal, full of black, turbid fluid, and having emptied it into a funnel, and allowed it to filter through a long tube, it came forth a clear, sweet-smelling liquid; and how, after a learned disquisition, Dr. Peedlewhisk promised, if they would elect him, to clarify the water of the silver-toned harmonists in like manner. Mr. Scruegut carried a key, which he said was made from the philosopher's stone, and by which he said he could unlock or lock up the bowels, or wind up the cords of life. Last of all came in a short, stout, little man, in white corded breeches and top-boots. He called himself Dr. Potthemwell, and placing one hand behind his back, and elevating the other in the air, assured the company that, according to his principles of physicking; it was better to keep the ship from leaking than to pump her dry when half full of water,-better to prevent the outbreak of fire, than to put the flames out when the house was gutted,and better, far better, to ward off disease altogether, than to eject the enemy when he had got possession of the citadel. In pursuance of this principie, he would, if they elected him their surgeon, adopt measures to prevent the invasion of sickness, and for this purpose would furnish them, ad libitum, on certain occasions during the year, with an excellent medicine, calculated to confirm and increase their stock of health. As an earnest of his good intentions, he had brought with him a bottle of this universal physic, which he invited the members to taste. This they had no sooner done than they expressed great approbation at its palatable and comforting qualities, and after short deliberation it was decided by a large majority that Dr. Potthemwell's qualification was vastly superior to that of any other doctor that had come before them that evening, and that he should be requested to procure an immediate supply of his medicine, in order that no time might be lost in attending to their health; for they had come to the resolution that Dr. Potthemwell should be the surgeon of the "United Society of Silver-toned Intellectual Harmonists."

A loud noise being heard without, I left the room to ascertain the cause, and found that Jack Threttle having spitefully informed Mr. Fischecrackum of Daisy Creaminy's departure from his ordinary sympathy with affliction's sons, in showing up Mr. Fischecrackum in a disparaging light, poor Daisy had brought down upon himself another martyrdom; for Fischecrackum was venting his rage and disappointment by administering to him kicks and pommellings in plentiful abundance. A general cheering at this point resounding from the club-room aroused me from my slumbers. I was much amused at the oddity of my dream, and in continuance of my first reflections, I hardly knew whether to be satisfied or sorry that there is still a wide field left open to which needy members of society, professional or non-professional, may retire when all other means fail, and by a diligent cultivation of the plant humbug reap a rich pecuniary harvest. Still I confess I am not destitute of a hope that a day will eventually arrive when the bulk of society will be deeply convinced, that in sickness, if legitimate medical science, and the accumulated experience of ages, cannot afford them a remedy, they will seek for it in vain at the hands of ignorance and quackery.

January, 1848 .

Sperans.

\section{MEDICAL FEES AT ASSURANCE OFFICES.}

To the Editor of THE LANCET.

SrR, - I forward to you a copy of a correspondence between myself and the secretary of the Temperance and General Provident Institution: make what use of it you may deem fit. The facts speak more loudly for themselves, perhaps, than if accompanied by any remarks.-I am, Sir, yours most respectfully,

Watford, Feb. 24th, 1848.

G. H. BETTS.

39, Moorgate-street, Feb. 18th, 1848.

Srr, - I have directed the parties named on the enclosed certificates to wait on you for examination. You will please to demand the fees marked, and forward the papers to the office.

G. H. Betts, Esq.

I am, your obedient servant,

\section{J. PHIr.lips, for Sec.}

Watford, Feb, 19th, 1848.

SIR,-I received this morning from your office three blank certificates to be filled up, and likewise a note, directing me to demand the several sums of $2 s .6 d ., 5 s$., and $5 s$, , from the parties presenting themselves for examination. My object in now addressing you is to ascertain from whom I may expect the remaining portion of the fees.-I am, Sir, yours respectfully, Mr. J. Phillips.

G. H. BetTs.

39, Moorgate-street, Feb. 19th, 1848.

SrR,-In answer to your note, I beg to enclose our scale of fees, which have been paid by us since the establishment of the institution.-I am, Sir, your obedient servant, G. H. Betts, Esq. John Phunitss.

Copy of Scale of Fees to Medical Referees.

The following fees will be paid by the persons examinedviz.,

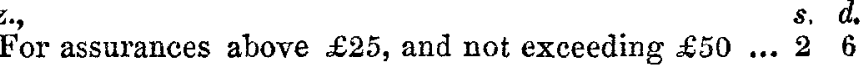

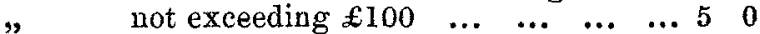

" exceeding $£ 100$, and under $£ 500 \quad \ldots 100$

" $" \quad £ 500$ and upwards ...

If the assurance be rejected by the Board, the fee is returned from the office to the proposer; but is in all cases retained by the medical man.

The medical referees are requested to be very careful in their examinations, and as explicit as possible in their reports, which are deemed confidential, and are on no account communicated to the assured.

Watford, Feb. 21st, 1848.

SrR, -I beg to acknowledge the receipt of yours of the 19th instant, and to state that I must decline the honour of earning 
half-a-crown, and two separate five shillings, by examining three individuals, and answering some fifty-four complex questions. I must likewise express my surprise that you should place so low an estimation on the value of a medical man's time and talents, as to expect that any one could furnish you with faithful reports and "careful examinations" for such fees. I am, Sir, yours, \&c.,

Mr. J. Phillips.

G. H. BeTts.

39, Moorgate-street, Feb. 22nd, 1848.

SIR,-I have read your letters, addressed to our clerk, Mr. Phillips, and have erased your name from our list of medical referees, as you decline to act on the terms accepted by the others. I have only to add, that as this institution was established with a special view to encourage the poorer classes in provident habits, we have been obliged to regulate our scale of fees accordingly. The usual fee is $10 s$; ; ours vary from $2 s .6 d$. to 20 s.-Your obedient servant,

Theodore Compton, Secretary.

Watford, Feb. 24th, 1848.

SIR,-I beg to acknowledge the receipt of yours of the 22 nd inst. Being from home, and particularly engaged, I had no opportunity of answering per return of post.

I am obliged by the erasure of my name from the list of medical referees, as by its continuance there I should feel I am not acting in conformity with the oath I took at the Royal College of Surgeons.

It is not my intention to enter into any discussion respecting the regulations of your Society. undoubtedly the motives which influenced your committee were of the purest and most philanthropic character, but I must add, the attempt " to encourage the poorer classes in provident habits," however praiseworthy in itself, ought not to be effected at the expense of the medical referee.

It appears to me that the graduated scale is impolitic in the extreme. For the examination of a person assuring for $£ 500$ the fee is stated to be $20 s$. How the medical testimony can be considered of only one-eighth of the value, in a person who assures for $£ 25, I$ am at a loss to conjecture, the more especially as in all cases the medical referees are requested to be "very careful in their examinations, and as explicit as possible in their reports."

I am, Sir, yours respectfully,

Theodore Compton, Esq.

G. H. Betrs.

\section{PUBLTC HEALTH BILT.}

\section{To the Editor of THE LANOET.}

COPY OF A LETTER TO THE RIGHT HON. LORD MORPETH, M.P.

Mr LORD,-For a long series of years the medical profession have taken a deep and an untiring interest in promoting the health of the community, and have throughout been mainly instrumental in awakening the public mind to a sense of the large amount of mortality which results from preventible causes. Amid severe labour, dangers, and discouragements, such as no other class of men can be found cheerfully to endure, they have, on every fitting occasion, promulgated enlightened views for the preservation of the public health and have amassed abundant evidence, at every personal risk, of convincing those less capable of forming an opinion, of the concealed causes of disease and death. And what is the reward for their disinterestedness and devotion, in order to attain the security of the public health? My Lord, I deeply regret to say that $I$ consider, in the Public Health Bill, as it at present stands, the whole profession of medicino have been slurred over in a manner by no means creditable. I conceive, that a Sanitary Bill ought to have the medical profession for its base,-that its apex should be adorned by one of the same body, and that its details might be confidently committed to its hard-worked, but ill-paid, members. What class of men, both by education and experience, can be so capable of superintending the public health, and of carrying out the full provisions of a sanitary measure? Can the lawyer, or the engineer, act in any other capacity than as subsidiaries to the medical officer of health? Is either one or the other, if left alone, a fit and proper person to supersede the appointment of an officer of health? $\mathrm{My}$ Lord, I think not-and I humbly crave your Lordship's serious re-consideration of this important point. Does the lawyer, the engineer, or any other person but the medical man, investigate the latent causes of disease and death,-frequent the haunts of misery and destitution,-examine with his own eyes the manifold nuisances which are allowed insidiously to undermine the public health, -and is it easy for any but a medical man fittingly to suggest an appropriate remedy? These are simple questions, my Lord, but they are worthy of profound consideration. Place and patronage should extend in this case to the choice of properly qualified persons, and I hold your Lordship in so great estimation as to believe that you will yet render the profession that justice to which it is pre-eminently entitled. The profession have but few advocates in parliament. Would that parliament contained a larger number of medical men among its honourable members! Such an addition would not impede the formation of good and scientific laws, and in all that relates to the health of the people, they, in particular, would be eminently calculated to legislate.

Permit me, my Lord, to write a few words more. Your Lordship has spoken feelingly of the arduous labours and perilous duties of the medical man; and now that it is in your Lordship's power to connect him with the superintendence of the public health, you are induced to make no provision for his appointment, but will leave him to be selected or not, as interest or faction may predominate. This is a course which I deeply regret.

One other point remains, and $I$ have done. Where is there a man so deserving of any patronage and support your Lordship can bestow in this instance, as the medical officer under the poor-law? He is acquainted with every hole, cranny, and pestilential nuisance in his district; he visits them daily, and hourly risks his life in the performance of his dangerous duty. Reflect for a moment, my Lord, on the trials he has to endure, the misery he has unremittingly to witness,-aye, and out of the pittance he receives, frequently to relieve; think that there is no provision for his family, in case he fall a victim; and if, after this, your Lordship will still look unkindly on him, then his only plan is to endure yet a little longer, until his plea and his deserts shall find a more considerate advocate. -I have the honour to be, my Lord, your Lordship's obedient servant,
Cheapside, Halifax, 1848 .
Frederick Smith Garlick.

\section{THE PUBLIC HEALTH BILL AND ITS SHORT- COMINGS.}

\section{To the Editor of THE Lavcet.}

SxR,-I was glad to see your observations upon the illusage medical practitioners are meeting with from Lord Morpeth and the sanitary reformers. I have ever been a strong advocate in favour of sanitary measures, and have considerably regretted the rejection of each Bill, as they have been successively brought forward.

There appears, however, no reason to suppose the present measure will meet a similar fate, and delighted as $\bar{I}$ am at this idea, I cannot but feel great regret at the curtailing it has undergone from its predecessors ; nor am I satisfied that the present measure will not prove almost as inoperative as the celebrated "Removal of Nuisances", 9 \& 10 Vict. c. 96 . A hasty glance has suggested the absurdities $I$ intend point ing out, and I have no doubt that, if my time permitted, others equally as ridiculous would soon be discovered.

First.-Scarcely any of the measures are compulsory, but left to the discretion of local boards, of whose disinclination to advance beyond their present horrible position, in this place at least, I have long had proof.

Second.-In clause thirty-nine the local boards are to fill up "all ponds, drains, and places containing water, matter, or thing of an offensive nature, likely to be prejudicial to health." In clause forty, "if at any time it appears to the inspector of nuisances that any accumulation of dung \& $c_{\text {., or other }}$ noxious or offensive matter, ought to be removed \&c.;" and in clause forty-one, "if, upon the certificate of the inspector of nuisances, it appears to the local board that any house is in such a filthy or unwholesome condition that the health of any person is affected or endangered thereby, or that that whitewashing \&c. would tend to prevent or check infectious or contagious diseases \&c."

Now, Sir, you and I, as professional men, should naturally have anticipated that the man who was to have certified in these cases would have been a member of the medical profession; but no, he will in all probability be a surveyor, or he may be a chimney-sweep. I need not ask what they can know as to the checking or preventing contagious diseases !

Take, however, one of their certified nuisances, and the defendant produces a medical man, who proves that it is not detrimental to health. I take it, in such a case, the plaintiff must be non-suited. Was there anything here so ridiculous ? I may add, that $I$ have asked the opinion of one well versed in law on this point, and he fully concurs with me.

The absurdity is not at all diminished in the sixty-eighth 